\title{
Profil Penderita Morbus Hansen (MH) di Poliklinik Kulit dan Kelamin RSUP Prof. Dr. R. D. Kandou Manado Periode Januari - Desember 2013
}

\author{
Andiswati Desrina, ${ }^{1}$ Grace M. Kapantow, ${ }^{2}$ Renate T. Kandou ${ }^{2}$
}

\author{
${ }^{1}$ Program Studi Pendidikan Dokter Fakultas Kedokteran Universitas Sam Ratulangi Manado \\ ${ }^{2}$ Bagian/SMF Ilmu Penyakit Kulit dan Kelamin Fakultas Kedokteran Universitas Sam \\ Ratulangi/RSUP Prof. Dr. R. D. Kandou Manado \\ Email: disa.desrina26@gmail.com
}

\begin{abstract}
Morbus Hansen (MH) is still a public, social, and rehabilitation problems due to the physical disability resulted from delayed or inadequate treatment. This study was aimed to obtain the profile of MH patients at the Dermatovenerology clinic, Prof. Dr. R. D. Kandou Hospital Manado in the period of January to December 2013. This was a descriptive and retrospective study. The results showed that there were $98 \mathrm{MH}$ patients consisting of 69 males $(70.4 \%)$ and 29 females $(29,6 \%)$. The majority of patients were $25-44$ years old $(47.0 \%)$ with multibacillary type (93.9\%). Most patients did not show lepra reaction (67.3\%); erythema nodosum leprosum (ENL) reaction was found in $29.6 \%$ of patients, and reversal reaction in $3.1 \%$ of patients. As many of $29.6 \%$ had been treated with multidrug therapy (MDT), and 10.2\% did not, meanwhile, $60,2 \%$ of patients did not have any data of treatment. In conclusion, the majority of MH patients at the Dermatovenerology clinic, Prof. Dr. R. D. Kandou Hospital Manado in the period of January to December 2013 were males, aged 25-44 years, had multibacillary type with ENL reaction, and had been treated with MDT.
\end{abstract}

Keywords: Morbus Hansen profile

\begin{abstract}
Abstrak: Morbus Hansen (MH) masih merupakan masalah kesehatan, sosial, dan rehabilitasi oleh karena kecacatan fisik yang terjadi akibat pengobatan yang terlambat atau tidak memadai. Penelitian ini bertujuan untuk mengetahui profil penderita MH di Poliklinik Kulit dan Kelamin RSUP Prof. R. D Kandou Manado periode Januari-Desember 2013. Jenis penelitian ialah deskriptif retrospektif. Hasil penelitian mendapatkan 98 penderita $\mathrm{MH}(6,72 \%)$ dari total 1457 pasien, terdiri dari 69 laki-laki $(70,4 \%)$ dan 29 perempuan $(29,6 \%)$. Mayoritas penderita berada pada rentang usia 25-44 tahun (47,0\%) dengan tipe MH multibasiler (93,9\%). Pada sebagian besar penderita tidak didapatkan reaksi lepra (67,3\%); reaksi erythema nodosum leprosum (ENL) didapatkan pada $29,6 \%$ penderita dan reaksi reversal pada 3,1\% penderita. Mengenai riwayat pengobatan, sebesar 29,6\% telah mendapat pengobatan multidrug therapy (MDT) sebelumnya dan $10,2 \%$ belum pernah mendapatkan pengobatan MDT, namun sebesar $60,2 \%$ penderita tidak memiliki data pengobatan. Simpulan penelitian ini ialah mayoritas penderita MH di Poliklinik Kulit dan Kelamin RSUP Prof. R. D Kandou Manado periode Januari-Desember 2013 berjenis kelamin laki-laki, usia 25-44 tahun, tipe MH multibasiler, dengan reaksi ENL, dan pernah mendapat pengobatan MDT.
\end{abstract}

Kata kunci: profil Morbus Hansen

\section{PENDAHULUAN}

Morbus Hansen (MH) atau dikenal dengan kusta termasuk penyakit tertua. Kata kusta berasal dari bahasa India Kustha, telah dikenal sejak 1400 tahun sebelum masehi.
Kata kusta disebut dalam kitab injil, terjemahan dari bahasa Hebrew zaraath, yang sebenarnya mencakup beberapa penyakit kulit lainnya. Ternyata deskripsi mengenai penyakit ini sangat kabur bila 
dibandingkan dengan kusta yang dikenal sekarang. Penularan Morbus Hansen dapat disebabkan oleh percikan droplet dari penderita kusta secara terus menerus dalam waktu yang lama. Pada permulaan tahun 2009 tercatat 213.036 kasus yang berasal dari 121 negara, sedangkan jumlah kasus baru pada tahun 2008 tercatat 249.007. ${ }^{1}$

Pada tahun 1991 World Health Assembly membuat resolusi yaitu Eliminasi Kusta Tahun 2000. Upaya pengendalian penyakit kusta di dunia menetapkan tahun 2000 sebagai tonggak pencapaian eliminasi. Di Indonesia hal ini dikenal sebagai Eliminasi Kusta Tahun 2000. ${ }^{1}$

Morbus Hansen terdapat di seluruh dunia, terutama di Asia, Afrika, Amerika latin, dan juga tersebar di daerah tropis dan subtropis, terutama pada masyarakat yang sosioekonominya rendah. ${ }^{1} \mathrm{Di}$ Indonesia, penderita $\mathrm{MH}$ pada anak di bawah usia 14 tahun didapatkan sekitar 11,39\%, dan jarang sekali ditemukan pada anak di bawah usia 1 tahun. Frekuensi usia terbanyak yaitu pada usia 25-35 tahun. Laki-laki lebih banyak terinfeksi dibandingkan perempuan dengan perbandingan $2: 1 .^{2}$

Penelitian pada tahun 2012 di RSUP Prof. Dr. R. D. Kandou Manado menunjukkan bahwa dari 112 kasus $\mathrm{MH}(10,22 \%)$ terbanyak berasal dari kelompok usia 25-44 tahun (46,4\%), jenis kelamin laki-laki $(64,3 \%)$, tempat tinggal Kecamatan Singkil $(12,5 \%)$, tipe $\mathrm{MH}$ terbanyak multibasiler $(89,3 \%)$, terdapat reaksi ENL (16\%), kecacatan tingkat $2(8,1 \%)$, dan riwayat pengobatan terbanyak belum pernah melakukan pengobatan MDT sebelumnya $(54,5 \%){ }^{2}$

Di Indonesia, distribusi tidak terjadi secara merata dan tertinggi terdapat di Pulau Jawa, Sulawesi, Maluku dan Papua. ${ }^{3}$

Mengingat masih tingginya prevalensi MH di Indonesia dan kecacatan yang dapat terjadi maka penulis terdorong untuk meneliti profil penderita Morbus Hansen $(\mathrm{MH})$ di Poliklinik Kulit dan Kelamin RSUP Prof. Dr. R. D. Kandou Manado periode Januari - Desember 2013.

\section{METODE PENELITIAN}

Penelitian ini menggunakan data rekam medik pasien dan buku register Morbus Hansen Bagian Ilmu Penyakit Kulit dan Kelamin RSUP Prof. Dr. R. D. Kandou Manado. Jenis penelitian ini ialah deskriptif retrospektif.

Populasi penelitian mencakup seluruh data pasien yang berobat di Poliklinik Kulit dan Kelamin RSUP Prof. Dr. R. D. Kandou Manado periode Januari-Desember 2013. Sampel penelitian yaitu kasus $\mathrm{MH}$ yang tercatat di Poliklinik Kulit dan Kelamin RSUP Dr. R. D Kandou periode Januari Desember 2013. Variabel penelitian meliputi usia, jenis kelamin, tipe, reaksi, dan riwayat pengobatan.

\section{HASIL PENELITIAN}

Berdasarkan penelitian retrospektif yang dilakukan di Poliklinik Kulit dan Kelamin serta Pusat Rekam Medik RSUP Prof. R. D. Kandou, pada pasien yang didiagnosis $\mathrm{MH}$ periode Januari-Desember 2013 didapatkan berjumlah 98 kasus $\mathrm{MH}$ $(6,72 \%)$ dari total 1457 pasien yang datang berobat. Berdasarkan jenis kelamin, kasus MH didapatkan lebih banyak pada jenis kelamin laki-laki yaitu sebanyak 69 kasus (70,4\%) sedangkan pada jenis kelamin perempuan sebanyak 29 kasus $(29,6 \%)$.

Tabel 1 memperlihatkan distribusi kasus MH berdasarkan usia. Kasus terbanyak didapatkan pada usia 25-44 tahun, yaitu 46 kasus (47,0\%). Tidak didapatkan kasus $\mathrm{MH}$ pada kelompok usia di bawah 4 tahun.

Tabel 1. Distribusi kasus MH berdasarkan usia

\begin{tabular}{ccc}
\hline $\begin{array}{c}\text { Usia } \\
\text { (tahun) }\end{array}$ & Jumlah & $\begin{array}{c}\text { Persentase } \\
(\%)\end{array}$ \\
\hline$<1$ & 0 & 0 \\
$1-4$ & 0 & 0 \\
$5-14$ & 5 & 4,1 \\
$15-24$ & 21 & 21,4 \\
$25-44$ & 46 & 47,0 \\
$45-64$ & 20 & 20,4 \\
$>65$ & 7 & 7,1 \\
Total & 98 & 100 \\
\hline
\end{tabular}

Jumlah kasus MH multibasiler di Poliklinik Kulit dan Kelamin RSUP Prof. Dr. R. D. Kandou pada periode Januari-Desember sebanyak 92 kasus (93,9\%), dan yang 
pausibasiler terdapat 6 kasus $(6,1 \%)$.

Tabel 2 memperlihatkan bahwa reaksi erythema nodosum leprosum (ENL) didapatkan pada 29 penderita $(29,6 \%)$ sedangkan reaksi reversal pada 3 penderita $(3,1 \%)$. Namun demikian, terdapat 66 penderita $(67,3 \%)$ yang tidak memperlihatkan reaksi.

Tabel 2. Distribusi berdasarkan tipe reaksi

\begin{tabular}{lcc}
\hline Reaksi MH & Jumlah & $\begin{array}{c}\text { Persentase } \\
(\boldsymbol{\%})\end{array}$ \\
\hline Reaksi ENL & 29 & 29,6 \\
Reaksi reversal & 3 & 3,1 \\
Tidak ada reaksi & 66 & 67,3 \\
Total & 98 & 100 \\
\hline
\end{tabular}

Tabel 3 memperlihatkan bahwa berdasarkan riwayat pengobatan sebelumnya, terdapat 29 kasus $(29,6 \%)$ yang menerima pengobatan multidrug therapy (MDT); 10 kasus $(10,2 \%)$ belum pernah menerima pengobatan MDT sebelumnya; dan 59 kasus $(60,2 \%)$ yang tidak memiliki data riwayat pengobatan.

Tabel 3. Distribussi berdasarkan riwayat pengobatan sebelumnya

\begin{tabular}{ccc}
\hline $\begin{array}{c}\text { Riwayat } \\
\text { pengobatan }\end{array}$ & Jumlah & $\begin{array}{c}\text { Persentase } \\
(\mathbf{\%})\end{array}$ \\
\hline Ya & 29 & 29,6 \\
Tidak & 10 & 10,2 \\
Tidak ada data & 59 & 60,2 \\
Total & 98 & 100 \\
\hline
\end{tabular}

\section{BAHASAN}

Pada penelitian retrospektif yang dilakukan di Poliklinik Kulit dan Kelamin RSUP Prof. Dr. R. D. Kandou Manado periode Januari-Desember 2013 didapatkan sebanyak 98 kasus penderita Morbus Hansen $(6,72 \%)$ dari 1.457 kasus yang berobat. Jumlah kasus ini mengalami penurunan dibandingkan penelitian sebelumnya oleh Tiwow et $\mathrm{al}^{2}$ di Poliklinik Kulit dan Kelamin RSUP Prof. Dr. R. D. Kandou Manado tahun 2012 yaitu sebanyak 112 kasus (10,22\% dari total kasus). ${ }^{2}$ Kurangnya pengetahuan masyarakat tentang $\mathrm{MH}$ menyebabkan tingginya jumlah penderita pada tahun 2012.

Ditinjau dari segi usia, angka kasus terbanyak pada kelompok usia 25-44 tahun
(47,0\%), diikuti oleh kelompok usia 15-24 tahun $(21,4 \%)$. Pada kelompok usia <4 tahun tidak ditemukan kasus MH (Tabel 1). Tingkat insidensi Morbus Hansen pada usia 25-44 tahun kemungkinan karena masa inkubasi kusta yang sangat lama sehingga orang yang tertular pada usia muda baru muncul gejalanya pada usia yang lebih tua. Hasil penelitian ini selaras dengan penelitian oleh Tiwow et $\mathrm{al}^{2}$ yang juga mendapatkan persentase tertinggi penderita Morbus Hansen pada kelompok usia 25-44 tahun yaitu sebesar $46,4 \%$.

Berdasarkan jenis kelamin, laki-laki didapatkan lebih banyak daripada perempuan yaitu $70,4 \%$ vs $29,6 \%$. Hal ini sesuai dengan acuan pustaka yang menyatakan bahwa laki-laki lebih banyak terinfeksi daripada perempuan. Keadaan tersebut kemungkinan disebabkan karena laki-laki cenderung lebih sering beraktifitas di luar rumah, sehingga sering terpapar dengan penderita yang menjadi sumber infeksi yang berakibat risiko untuk tertular lebih besar daripada perempuan. ${ }^{4}$ Hasil penelitian ini selaras dengan penelitian oleh Varkevisser et al $^{5}$ tahun 2009 yang melaporkan bahwa penderita Morbus Hansen lebih banyak yang berjenis kelamin laki-laki di wilayah Asia. Tiwow et $\mathrm{al}^{2}$ juga mengungkapkan hal serupa dengan perbandingan laki-laki dan perempuan sebesar 1,8:1,18. Tingginya kejadian kusta pada laki-laki disebabkan oleh beberapa faktor, antara lain faktor lingkungan dan faktor biologik. ${ }^{4}$

Terdapat perbedaan regional dalam rasio jenis kelamin penderita kusta yang didiagnosis dan dirawat. Di negara-negara Asia, lebih banyak penderita laki-laki daripada perempuan yang terdaftar sementara di Afrika jumlah penderita perempuan melebihi jumlah laki-laki. The Netherlands Leprosy Relief (NLR) memulai penelitian tentang faktor-faktor yang mendasari perbedaan gender regional ini. Antara tahun 1997 dan 1999, tim pengendalian kusta di Indonesia, Nigeria, Nepal dan Brazil didukung oleh ilmuwan sosial/kesehatan masyarakat, melakukan penelitian eksplorasi komparatif. $^{4}$

Berdasarkan tipe $\mathrm{MH}$, multibasiler 
lebih banyak didapatkan daripada tipe pausibasiler yaitu $93,9 \%$ vs $6,1 \%$ (Tabel 3 ). Sumber infeksi penyakit MH ialah penderita dengan tipe multibasiler (MB). Cara penularan yaitu melalui kontak langsung yang lama dan erat. Pendapat lain menyatakan adanya penularan secara inhalasi sebab Mycobacterium leprae masih dapat hidup beberapa hari dalam droplet. Masa tunas $\mathrm{MH}$ bervariasi dari 40 hari sampai 40 tahun. ${ }^{1}$

Dari klasifikasi reaksi Morbus Hansen, reaksi ENL lebih banyak ditemukan daripada reaksi reversal yaitu $29,6 \%$ vs $3,1 \%$. Namun terdapat $67,3 \%$ kasus yang tidak mengalami reaksi ENL maupun reversal. Hal ini senada dengan hasil penelitian yang dilakukan oleh Tiwow et $\mathrm{al}^{2}$ di Rawat Inap RSUP Prof Dr. R. D. Kandou tahun 2012, yang juga melaporkan bahwa pasien $\mathrm{MH}$ dengan reaksi ENL lebih banyak ditemukan daripada reaksi reversal (16\% vs 3,6\%). Reaksi ENL timbul terutama pada tipe borderline lepromatosa (BL) dan multibasiler sehingga makin tinggi tingkat multibasiler maka makin besar pula kemungkinan timbulnya ENL. ${ }^{2}$

Ditinjau dari riwayat pengobatan sebelumnya, didapatkan $29,6 \%$ kasus pernah menerima MDT sebelum datang ke Poliklinik Kulit dan Kelamin RSUP Prof. Dr. R. D. Kandou Manado, dan 10,2\% tidak pernah memiliki riwayat pengobatan MDT. Selain itu, terdapat $60,2 \%$ kasus yang tidak memiliki data riwayat pengobatan.

Pada penderita $\mathrm{MH}$ yang telah menyelesaikan terapi MDT dengan MI 0\% didapatkan viabilitas Mycobacterium leprae positif dengan metode RT-PCR. Spektrum klinis penderita yang ditentukan dari imunitas seluler nampaknya menjadi faktor terpenting dalam viabilitas Mycobacterium leprae. Riwayat pengobatan sebelumnya sangat penting untuk ditelusuri dalam upaya melakukan terapi lanjut agar dapat mencegah terjadinya reaksi MH. ${ }^{6}$

\section{SIMPULAN}

Pada periode Januari-Desember 2013 di Poliklinik Kulit dan Kelamin RSUP Prof. Dr. R. D. Kandou Manado didapatkan mayoritas penderita Morbus Hansen ialah jenis kelamin laki-laki, usia 25-44 tahun, tipe multibasiler, dengan reaksi ENL, dan pernah mendapat pengobatan MDT.

Perlu dilakukan penelitian lebih lanjut tentang faktor-faktor yang menyebabkan peningkatan prevalensi Morbus Hansen. Selain itu diperlukan edukasi untuk meningkatkan kesadaran dan kepatuhan berobat dari penderita Morbus Hansen dan upaya penanggulangannya.

\section{Konflik Kepentingan}

Penulis menyatakan tidak terdapat konflik kepentingan dalam studi ini.

\section{DAFTAR PUSTAKA}

1. Menaldi S, Barmono K, Indriatmi W, editors. In: Ilmu Penyakit Kulit dan Kelamin (7th ed). Jakarta: Badan Penerbit Fakultas Kedokteran Universitas Indonesia, 2015; p. 87-.102.

2. Tiwow PI, Kandou RT, Pandeleke HEJ. Profil Pasien Morbus Hansen di Poliklinik Kulit dan Kelamin BLU RSUP Prof. DR. R. D. Kandou. e-CliniC. 2014;2(1).

3. Amirudin MD, Hakim Z, Darwis E. Diagnosis penyakit kusta. In: Daili ES, Menaldi SL, Ismiarto SP, Nilasari H, editors. Kusta (1st ed). Jakarta: Fakultas Kedokteran Universitas Indonesia, 2003; p. 13

4. News Medical. What is Leprosy. 2013 Sept [cited 2016 Sept 5]]. Available from: http://www.news-medical.net/health/ What-is-Lepsory.aspx

5. Varkevisser CM, Lever P, ALubo O, Burathoki $\mathrm{K}$, Idawani C, Moreira TMA, et al. Gender and leprosy: case studies in Indonesia, Nigeria, Nepal and Brazil. Lepr Rev. 2009;80(1):65-76.

6. Emmy S, Sjamsoe D. Buku Kusta. (2nd ed). Jakarta: FKUI, 2006. Available from: http://microbewiki.kenyon.edu/mediaw iki- 1.6.6/index.php/Mycobacterium 